\title{
Outcome of Keloid's Treatment in a Tertiary Care Hospital
}

\author{
Karn $\mathrm{B}^{1}$ Mishra SM ${ }^{2}$
}

\begin{abstract}
Introduction: Keloids are characterized by their continued growth following trauma, extension into normal tissue and their high recurrence rate following excision. Keloids are common following ear piercing or flame burns. These lesions are highly conspicuous and cosmetically unappealing. Multiple methods including surgery, radiotherapy, antimitotic agents, silicone sheet, pressure clips and cryotherapy have been advocated. The risk of recurrence and the need to prevent distortion of following resection is a challenge to the surgeon. Material and Methods: A total of 46 patients with keloid were treated at the plastic surgery department of the Nepalgunj Medical College between January 2013 to March 2017. The patients were divided in two groups. Group A consisted of 24 patients with keloid in their ear where complete excision of keloid was done with tension free repair and was supplemented with intralesion triamcinolone injection at the time of operation and thereafter as and when needed. Group B consisted of 22 patients. Out of these 15 patients had keloid over the anterior chest wall and rest 07 had keloid over the deltoid region. These cases received intralesional triamcinolone only, a total of 5 such injections at month interval as a tension free repair after excision was not considered feasible. Results \& Conclusion: Patients in Group A underwent surgical excision and intra and post operative intralesional steroids and patients in Group B received 4 weekly intralesional injection of triamcinolone injection $40 \mathrm{mg}$. Out of 24 keloid in Group A two developed post-excision recurrence during a mean follow-up period of 24 months. However they regressed with subsequent local injection of steroid. The group B consisting of scar over the deltoid region and anterior chest wall were not found suitable for excision as a tension free repair (a must to prevent recurrence) was not considered possible. Complete Excision of keloids with tension free suture and local steroid injection is a simple \& favoured technique for the management of keloid, it preserves contour \& skin quality and has a low recurrence rate. Unfortunately all cases are not suitable for total surgical excision. In such cases, steroid locally has to given locally at monthly intervals. The keloids regresses, but atrophy and depigmentation at the site of injection are the complications.
\end{abstract}

Key Words: Combination therapy, fillet flap, intralesional steroid, keloid, keloid recurrence

\section{INTRODUCTION}

Keloids are characterised by their continued growth following trauma, extension into normal tissue and their high recurrence rate following excision. Keloids are common following ear piercing or flame burns. These lesions are highly conspicuous and cosmetically unappealing. It is well known that keloids are "Confused scars that do not know when to stop growing". The basic pathology is an imbalance between anabolic (proliferation) and catabolic (apoptotic) phases of the healing process ${ }^{1}$.

The various treatment modalities so far described in managing keloids are surgical excision, intralesional steroidal injections, compression therapy with silicon sheets, cryotherapy, laser, $\alpha$ $2 \mathrm{~b}$ interferon and chemotherapeutic agents like 5 -fluorouracil ${ }^{2,3}$. Surgical excision totally eliminates the lesion but the main disadvantage is $\geq 50 \%$ recurrence if used alone ${ }^{3}$. The

1. Dr. Binod Karn

2. Prof. S. M. Mishra

\section{Address for correspondence:}

Dr. Binod Karn

Department of Surgery (Burn \& Plastic Unit)

Nepalgunj Medical College Teaching Hospital

Kohalpur, Banke, Nepal

E-mail: drbin2007@gmail.com disadvantage with the other procedures is incomplete ablation of the lesion leaving poor aesthetic results. To remove the lesions totally and to prevent recurrence needs "surgical excision in combination with one or more of the other modalities of treatment"12-7. It is also true that surgical excision with tension free repair (a prerequisite against recurrence) is not possible in all cases. Hence intralesional steroids remains only available treatment for such cases.

\section{MATERIAL AND METHODS}

The study was carried out on 46 patients admitted to the plastic surgery unit of NGMC between January 2013 to March 2017. These 46 patients with keloid, location wise distribution was external ear -24 , anterior chest wall -15 and skin over the deltoid region -7. The patients were divided into group $(A)$ and group (B). Group A consisting of keloid on ear (total 24) were subjected to complete excision of keloid and were given triamcinolone injection locally at the margin of excision intra operatively after suture and also in the post-operative period as and when required. Patients with keloid over chest wall and deltoid region were not operated because unlike ear a tension free repair after operation was not possible in the chest wall or deltoid which is an essential prerequisite of keloid surgery (if recurrence of keloid is to be prevented). The diabetic patients were excluded from the study. 


\section{Group A (Keloid on the external ear)}

Surgical excision + inj. Triamcinolone $(40 \mathrm{mg} / 2 \mathrm{cc})$ at the margin of the suture. The patients underwent excision of keloid using keloid fillet flap and intra-lesional steroid was injected into margins of suture intra-operatively. Steroid used was triamcinolone acetonide $20 \mathrm{mg} / \mathrm{cc}$, diluted in ratios with equal quantity of $2 \%$ lignocaine. Special emphasis were on achieving a tension-free closure, accurate coaptation of skin edges, adequate haemostasis, atraumatic handling of tissues and asepsis. A pressure dressing was applied at the end of surgery for 48 hours. Suture removal was done on the 14th day. Intralesional triamcinolone was reserved for those who showed clinical evidence of recurrence during the follow-up and had three injections at monthly intervals. Two cases of this group needed injection as they showed early sign of recurrence. Follow-up was at monthly intervals for three visits followed by quarterly visits until the end of the 1st year and biannual visits until the end of the 2 nd year. All cases were followed up for 2 years.

\section{Group B}

Consisted of 22 patients with keloids. 15 of them had on the anterior chest wall and 7 on the deltoid region. All these cases were treated with Intralesional triamcinolone: Triamcinolone $40 \mathrm{mg} / 2 \mathrm{cc}$ was given intralesionally at the interval of 1 month from $1^{\text {st }}$ visit to $4^{\text {th }}$ monthly visits. They were not subjected to excision as a tension free repair was considered not possible.

\section{RESULTS}

46 patients with keloid were included in the study. Group A patient which had keloid on ear (following piercing of ear lobule) had complete excision of the keloid with tension free repair. They showed uneventful post operative period except $2(8.33 \%)$ patients where there was evidence of early recurrence. Out of these two, one had mild infection (redness after removal of stiches). The case with infection was treated with oral cephelexim ( 5 days) and local betadine application. After the infection settled, this patient received two local injections of triamcinolone $40 \mathrm{mg}$ at monthly interval. The keloid disappeared. Another without infection also received three injections of triamcinolone at monthly interval. The keloid disappeared in this case as well. There was no evidence of depigmentation or atrophy of skin in any case.

Group B: consisted of 22 patients. The location of keloid was on anterior chest wall (15) and over the deltoid region (7). They received intralesional triamcinolone at monthly interval, a total of 5 injection. All case showed disappearance of the keloid but all of them showed depigmentation of skin and atrophy of the skin following injection. However after the lapse of a year, local pigmentation and atrophy at the injection site improved and was more acceptable to the patients.

\begin{tabular}{|l|c|c|}
\hline $\begin{array}{l}\text { Age group } \\
\text { (years) }\end{array}$ & $\begin{array}{c}\text { Number of } \\
\text { Patients }\end{array}$ & Percentage \\
\hline $15-20$ & 7 & $15.21 \%$ \\
\hline $21-25$ & 18 & $39.13 \%$ \\
\hline $26-303$ & 12 & $26.08 \%$ \\
\hline $1-35$ & 9 & $19.56 \%$ \\
\hline
\end{tabular}

Table I: Age distribution

\begin{tabular}{|l|c|c|}
\hline $\begin{array}{l}\text { Anatomical site } \\
\text { of Keloid }\end{array}$ & $\begin{array}{c}\text { Number of } \\
\text { Patients }\end{array}$ & Percentage \\
\hline Ear & 24 & $52.17 \%$ \\
\hline Anterior Chest & 15 & $32.60 \%$ \\
\hline Deltoid Region & 7 & $15.21 \%$ \\
\hline
\end{tabular}

Table II: Anatomical site of Keloid

\begin{tabular}{|l|c|c|}
\hline $\begin{array}{l}\text { Sex of the } \\
\text { patients }\end{array}$ & $\begin{array}{c}\text { Number of } \\
\text { Patients }\end{array}$ & Percentage \\
\hline Male & 17 & $36.95 \%$ \\
\hline Female & 29 & $63.04 \%$ \\
\hline
\end{tabular}

Table III: Sex distribution

\begin{tabular}{|l|c|c|c|}
\hline Group & Recurrence & Infection & $\begin{array}{c}\text { Depigmentation } \\
\text { and Atrophy } \\
\text { of dermis }\end{array}$ \\
\hline Group A & $2(8.33 \%)$ & $1(2.171 \%)$ & 0 \\
\hline Group B & nil & nil & $22(47.82 \%)$ \\
\hline
\end{tabular}

Table IV: Complications following treatment (at the $1^{\text {st }}$
follow up)

\section{DISCUSSION}

24 patients in this series got their ears pierced after the age of ten years. This correlates well with the fact that the risk of keloids increases with each subsequent piercing, especially when the piercing is after ten years of age ${ }^{9}$.

The average duration of lesions in this study is 3.8 years and most of them had tried intralesional triamcinolone unsuccessfully. Pressure therapy could not be applied as custom-made devices are not available here and patients are not interested in using them. So, the only way of treating them was surgery.

It has been proven beyond doubt that surgical excision alone has very high recurrence rates ranging from 50 to $100 \%^{2,3,4,10}$. But surgical excision is a sure and predictable way of removing 
the lesion in toto but needs to be combined with other modalities. While treating keloids of exposed body parts like the ears, the aesthetic concern is as important as symptomatic improvement.

Meticulous surgical technique was used for all the cases in this series and care was taken against five proven factors (incomplete removal of keloid/scar tissue, haematoma, infection, tension on suture line and poor vascularity to wound edges) that cause undesirable scars ${ }^{4,11}$.

One patient from Group A, who had postoperative infection showed recurrence ${ }^{5}$ during the first postoperative visit, i.e., at about one month from the time of surgery. The other one patient who showed recurrence at the point of maximum tension over the suture line within one month of surgery and was promptly controlled by the local triamcinolone injection.

Recurrence in all above 2 patients was easily controlled with Intralesional triamcinolone.The message is very clear that after excision if there is tendency for keloid, it must be promptly treated by local steroids to prevent recurrence otherwise one is sure to be rewarded by a recurrence. Depigmentation and atrophy of dermis were seen with all patients as a result of Intralesional triamcinolone therapy ${ }^{2,6}$. Pigmentation as well as atrophy were restored over a few months without any treatment.

\section{CONCLUSION}

Surgical excision of keloids supplemented with Intralesional triamcinolone with regular clinical follow-up appear to be a very reliable method with very few complications ${ }^{2-7}$. Meticulous surgical technique observing precautions against undesired scarring (complete removal of Keloid/scar tissue, hemostasis, asepsis, tension-free suture line and good vascularity to wound edges) is more important than the length of the scar ${ }^{11}$. Clinically what is most difficult to achieve is a 'tension-free suture line' which is the culprit for recurrence. Achieving a tension-free suture line is relatively more feasible with ear keloids than with lesions over many other parts of the body ${ }^{4}$.

What appears to be most important in preventing recurrence and a new finding with this study is 'regular clinical follow-up to encounter the early recurring lesion', which responds in $100 \%$ of the cases to Intralesional triamcinolone in 2-3 sittings at monthly intervals.

\section{REFERENCES}

1. Luo S, Benathan M, Raffoul W, Panizzon RG, Egloff DV. Abnormal balance between proliferation and apoptotic cell death in fibroblasts derived keloid lesions. Plast Reconstr Surg 2001;107:87-96.

2. Berman B. Departments of Dermatology and Internal Medicine, University Of Miami School of Medicine eMedicine - Keloid and hypertrophic scar. Available from: http://www.emedicine.com/derm/topic205.htm-105k.

3. Al-Attar A, Mess S, Thomassen JM, Kauffman CL, Davison SP. Keloid pathogenesis and treatment. Plast Reconstr Surg 2006;117:286-300.

4. Ogawa R, Mitsuhashi K, Hyakusoku H, Miyashita T. Postoperative electron-beam irradiation therapy for keloids and hypertrophic scars: Retrospective study of 147 cases followed for more than 18 months. Plast Reconstr Surg 2003;111:547-53.

5. Ragoowansi R, Cornes PG, Moss AL, Glees JP. Treatment of keloids by surgical excision and immediate postoperative single-fraction radiotherapy. Plast Reconstr Surg 2003;111:1853-9.

6. Chaudhry MR, Akhtar S, Duvalsaint F, Garner L, Lucente FE. Ear lobe keloids, surgical excision followed by radiation therapy: A 10-year experience. Ear Nose Throat Jr 1994;73:779-81.

7. Ak фz T, Erdoran B, G фrgü M, Deren O. Combined approach to the treatment of earlobe keloids. Plast Reconstr Surg 1998;101:857-8.

8. Beausang $\mathrm{E}$, Floyd $\mathrm{H}$, Dunn $\mathrm{KW}$, Orton $\mathrm{Cl}$, Ferguson MW. A new quantitative scale for clinical scar assessment. Plast Reconstr Surg. 1998;102:1954-1961.

9. Barclay L, Lie D. Medscap-ear piercing at age 11 years or older may result in keloid formation in some children CME. Available online at http://www.medscape.com/viewarticle/504386 [Accessed on 12 January 2008].

10. Furnas DW. Complications of surgery of the external ear. Clin Plast Surg 1990;17:305-18.

11. Kim DY, Kim ES, Eo SR, Kim KS, Lee SY, Cho BH. A surgical approach for earlobe keloid: Keloid fillet flap. Plast Reconstr Surg 2004;113:1668-74. 